\title{
Environmental Management at Star Rated Hotel in Bali
}

\section{Jaya Pramono, I Ketut Budi Susrusa, and Agung Suryawan Wiranatha}

\author{
School of Postgraduate Study \\ Doctorate Degree in Tourism Udayana University \\ Coressponding author: jayapramono@gmail.com
}

\section{ARTICLE INFO}

Received

20 December 2013

Accepted

28 February 2014

Available online

10 March 2014

\section{ABSTRACT}

The outcomes of tourism in relation to the environmental sustainability is to preserve nature, environment, and resources availability. Therefore, the obligation to maintain sustainability of environmental are become a top agenda for the managers of the star-rated hotels. In line with this spirit the high growth of hotel and tourist arrival in Bali correlated with the high of resources use to meet the demand of hotel guests, it will affect to the environment of hotel and the environmental of Bali. This study surveyed 126 star hotels in Bali (which consists of four (4) one-star hotels, ten (10) two-star hotels, thirty-nine (39) three-star hotels, twenty-four (24) four-star hotels, and forty-nine (49) five star hotels, using a questionnaire, where the alternative answer used the seven (7) options, and the data were analyzed using descriptive statistics, and structural equation modelling (SEM). This study successfully established a significant model that describes the relationship between environmental issues, environmental management processes, and the benefits of environmental management processes in star rated hotels in Bali. Also the results of this research demonstrate that: 1 . There is a significant relationship between environmental issues to the process of environmental management at star rated hotels in Bali, and 2. There is a significant relationship between the process of environmental management to the the benefits of environmental management processes of the star rated hotels in Bali. Furthermore, the issues of environment is consists of: a. the issue of pressure from tour operator, $b$. the issue of customer and tourists' pressure, and $\mathrm{c}$. the issue of climate change. Then the environmental management process of hotel consists of: a. The wastewater management process, $b$. the solid waste management processes, and c. The chemical management processes, and finally the benefits of environmental management processes in star hotels are consists of: a. the sustaining the hospitality industry, b. the contribution to community development, and c. the satisfaction of the guests at star rated hotels in Bali. In accordance with these results is it suggested that every hotels are encouraged to do the process of environmental management because through this process, hotel will have a better relationship with the community, it had the preferred of tourists trend, it had become more prudent in term of resources use as a sustainable environmental efforts, and finally these can contribute to preserving the assets of the world for future generations.

Keywords: environmental management, star-rated hotel, Bali. 


\section{Introduction}

\section{Background}

The benefits of tourism in relation to environmental sustainability are the preservation of nature, and existing resources. It is stated as one of several major principles where tourism should preserve the nature and the environment, and based on these consequently, every businessman and tourists obliged to preserve environment, hereafter the environment will be healthy, clean, beautiful, and sustainable (The Laws of Indonesian Republic. No.10/2009 about Tourism). In line with this spirit, the obligation to maintaining environmental sustainability becomes the main agenda for the managers of the hotels.

Hotel as mentioned growing in Bali. According to Bali Tourism Authority, until 2014 the number of star rated hotel as many as 217 hotels, and supplying the availability as many as 29,541 rooms, and is directly proportional to the number of foreign tourists who came to Bali as many as $3,766,638$ tourists (8.72\% per year growth over the last 6 years). The high demand for rooms and the growth in the number of foreign tourists correlates with the high use of resources to meet the demands of these tourists. This trend could affect the environment, particularly around the hotel and finally the environmental conditions in Bali as an island, so that environmentally friendly increasingly prominent issue in the management of the hotel in Bali.

Carmona-Moreno, Céspedes-Lorente and De Burgos-Jiménez (2004) noted that there are two main reasons behind this attention to environmental issues. First, the public and the government has realized that, hotel as a commercial establishment has financial resources, practical knowledge, skill or expertise, and vision, should develop ecological solutions to environmental problems. Second, the ability to develop ecological solutions is closely related to the promotion of the hotel, because if hotel better to handling the environmental issues well and wisely, it will be a competitive advantage for the promotion of the hotel.
Bali as a tourist destination has already implementing the environmental management. Environmental management has been done for some star rated hotel located in Bali Tourism Development Corporation (BTDC) Nusa Dua. In addition, the research on the management of water and wastewater, has been conducted by Utami (2004) in Kuta; Lensiana (2010) in Ubud. Waste management and environmental concerns in the area of Seminyak, Jimbaran and Ubud, by Solihin (2014) and Hajjah and Decelle (2011). Dalem (2012) specifically explain some of the weaknesses in environmental management at star rated hotels in Bali.

In contrast to previous environmental studies, this study will discuss theoretically and contributes to the development concepts and tourism as a science, through the contribution of economics and environmental sciences, in particular how economics as a science will synergistic with the environment science will contribute to the environmental management process at star rated hotels and tourists satisfaction. This study also provides benefits in the field of environmental management practices particular in the operational activities and its organization in star rated hotels, such as the benefits to be received by the hotel from cutting operating costs, minimizing the consumption of resources, the water management, energy management, reduction of liquid and solid wastes management, and the management of purchasing of products for hotel operation, sspecially in terms of the process of environmental management at star rated hotels in Bali, with the general objective of this research is to analyze the environmental management at the star hotels in Bali.

\section{Research Objectives}

Objectives of this study are: (1) Testing the theoretical model that describes the relationship between issues, processes, and the benefits of environmental management processes in starrated hotels in Bali supported by empirical data, (2) Analyze the influence of environmental issues on the process of environmental management at the star hotels in Bali, (3) Analyze the influence the processes of environmental management to the benefit that perceived from environmental management processes at star rated hotels in Bali. 


\section{Literature Review}

\section{Environmental Management in Hotels}

The study of environmental management includes the study of all the technical and organizational activities aimed at reducing the environmental impact caused by company operations (Cramer, 1998). This definition at the hotel is a mission to reduce the environmental impact. Therefore the emphasis is demanding hotel manager to intentionally make decisions to reducing environmental impacts at the hotel. Environmental management involves various environmental initiatives that may differ in their implementation, depending on the type of industry, organizational characteristics, and their impact on the environment. Environmental management initiatives can be classified in several different categories such as technical and organizational prevention category, or category of pollution and pollution control (Russo and Fouts, 1997; Cramer, 1998).

From the business strategy point of view, the hospitality industry relatively new industry emerging and attracted a lot of interest from industry practitioners and researchers, particularly in terms of environmental management. The hospitality industry has traditionally been regarded as one of the industry which does not have a huge impact on the natural environment as compared to other industries such as gas and oil, and other industry products manufacturing. However the hotel is one of the key business sectors in the hospitality industry leading to more negative impact on the environment rather than on the supposed by the public, consume large amounts of non-durable goods, both local and imported goods, energy and water, and also produces large amounts carbon dioxide (Kirk, 1998; Bohdanowicz, 2006).

The efforts to identify the main motivation and incentives, in implementing environmentally friendly practices at the hotel has been done to improve the understanding of hotel management decision making, and determine the direction of environmental management in the hospitality industry. Many previous studies have identified the main force which determines the hotel management increasingly friendly to the environment, and it

http://ojs.unud.ac.id/index.php/eot appears on the hospitality industry that it has reached a consensus. Therefore the vast area of environmental management in hotel, lead the manager of the hotel to understand, that the difference in implementation process of environmental management at hotel, as a result of the different situational contexts, such as government regulations, public awareness about environmental issues, and the characteristics of the hotel.

\section{Issues, Processes and Benefits of Environmental Management in Hotels}

Kirk (1998) explore the benefits perceived by hotel managers from environmental management, based on these following indicators; improve profitability, increase customer and employee satisfaction, improved relations with the local community, public relations and marketing advantage over competitors, the results showed that the most significant benefit from the environmental management is the potential for increased public relations and better relations with local communities. Furthermore Bohdanowicz (2006) examined the environmental management at more than 600 hotels in Europe, found that this process will reducing the cost of operation as the most significant thing of the hotel, followed by the requests from customers, and improving the image of Hotel. Mensah (2006) investigated the management practices that are environmentally friendly hotel, and assess what is perceived hoteliers in Ghana. The result show that, providing a safe and healthy environment, quality of service of a clean environment, and reduce the costs of environmental hazards, are some of the main goals of environmental management.

Tzschentke, Kirk and Lynch (2008) through his research found that in hotels and small inns in Europe, hotel management practices towards environmentally friendly industry primarily driven by ethics and the economic considerations. The economic benefits have been considered as one of the most visible advantages of environmental management. A large amount of literature has highlighted the economic benefits of environmentally friendly practices as one of the main drivers towards green industry and environmental organizations concerned have proved quantitatively about this cost savings. 
Academic research also found that many economic benefits through resource efficiency as one of the significant driver to carry out environmental management (Iwanowski and Rushmore, 1994; Kirk, 1995; Bohdanowicz, 2006; Mensah, 2006).

There are some research in general industry emphasizing stakeholder relations as one of the external forces the most significant to encourage environmental management in companies (Banerjee, 2001; Yol Lee and Rhee, 2007). Some studies show empirical evidence where environmental management is driven by the influence of stakeholders such as governments, customers, and non-governmental organizations (NGOs). Government regulations are considered as one of the determinants where hotels in Malaysia will conduct environmental management. This regulation provides guidelines for the management of the hotel environment and strive to incorporate environmental management into the rating system. This has proven to be an effective mechanism to motivate the hotels to improve the practice of environmental management processes (Henriques and Sadorsky, 1996; Meegeren, 2001; Winter and May, 2001). Even when the rules have not been approved and no special penalties imposed (Khanna and Damon, 1999; H. Raedeke Charles H. Nilon, Andrew, 2001).

Related to customer participation Bohdanowicz (2006) identify the customer demand as the most influential initiatives for hotel manager in Europe to adopt environmentally friendly practices. Manaktola and Jauhari (2007) found that there is a significant relationship between customer attitudes and behavioral intentions for environmentally friendly industrial practices but does not indicate the willingness of customers to pay more for the management of environmentally friendly industry. Gustin and Weaver (1996) also found that the attitude of the hotel's customers, knowledge, and perceived self-efficacy has positive effect on customer behavior intention to stay in a hotel which is environmentally friendly. The majority of customers willing to participate in a reused towel program as a hotel customer participation in environmental programs.
In 1995 the International Hotel and Restaurant Association published a comprehensive environmental checklist and action guide development for small and medium-sized hotels. This publication helps hotels with more detailed information for environmental management systems. Almost all hotels have implemented this program with varying degrees of intensity. Surveys conducted on the implementation of this program shows that the most significant benefits of environmental management for the hotel is the improvement of public image and better relationships with the local community (Kirk, 1995). However for the hotel workers environmental policy is more beneficial in its financial management.

Environmental management at the hotel should include all activities that have an impact on the environment and develop practices wider to reduce them. For example in reducing the use of energy hotel managers have to control and improve ventilation and cooling equipment, lighting, and other facilities, which requires energy which is used in different areas. Similarly to reduce waste the hotel strives simultaneously minimizing the consumption of customers who use plastic wrapping, use of container that can be parsed again, reusable materials, such as glass, paper, and garbage collection were selected. However, as Brown (1994) notes although in some practice the hospitality industry have environmental labels the main reason the hotel will be involved in environmental management is because of the importance of regulation, resource saving and pressure from the Travel Bureau as well as customer / tourists.

\section{Conceptual Framework and Research Hypotheses}

\section{Conceptual Framework}

Tourism as an industry also contribute to the destruction of the environment. Carbon waste generated from the tourism sector and the sector of travel as much as 5\% and is projected to reach $130 \%$ in the future (UNWTO, 2009). This waste will damages the environment and causes pollution (a negative externality on the concept of market imbalance), so that the social and environmental costs in the production of tourism greater than the cost of production 
should be, or it can be said that for every tourism activity produced should including the social cost the costs incurred by the manufacturer coupled with the costs borne by society and the environment are exposed to pollution. This condition affects tourism trends and travel behavior because the tourism industry is very dependent on nature-based activities such as outdoor attractions and activities. Comfortable climatic conditions and safe at the destination is the primary motivation for visitors, and this is a positive effect on demand. While changes in temperature, rainfall, season, and rising sea levels will have an impact on nature and biodiversity and finally also in the travel industry and tourism itself. On the other hand tourism activities also contribute to climate change through greenhouse gas emissions, waste from tourism activity, energy use, and the other thing which is generated by transport and accommodation for tourists (Mycock and Baker, 2008). Accommodation sector (hotels), is known as an institution that is run commercially, and proved to have the financial resources, know-how, and a clear vision, should develop ecological solutions to various hotel environmental problems (Feiertag, 1994). The solution of this environmental problem at the hotel can be done through some practical activities such as energy saving measures, water, have an environmental policy in action and operations, the use of environmentally friendly products, collaboration with communities and local organizations and practices of sustainable ecotourism, management air quality, noise pollution control, managing the disposal of chemical substances, and toxic or hazardous materials (Alexander and Kennedy, 2002; Asean Green Hotel, 2012).

According to Cordeiro and Sarkis (1997), the planning and implementation of consistent environmental management at the hotel associated with economic principles, which gave rise to the concept of costs. According to Zhang, Joglekar Ph D and Verma Ph D (2010), by balancing productivity and environmental impact, environmentally sustainable operations, is one of the most promising measures, to control costs for the hotel. Houdré (2008), also added that this relates to the competitive advantage for the hotel, and on the other hand, dealing with government regulations. Therefore in order to become a sustainable tourism

http://ojs.unud.ac.id/index.php/eot destination the management of star rated hotel in Bali also must be sustainable, one of the things that needs to be done is to implement a process that embraces the hotel environmental management principles of sustainability The principles of sustainability occurs when environmental issues affect the process of environmental management, and further the process of managing this environment also affect the perceived benefits of the hotel, in terms of financial benefits, employee satisfaction, biodiversity and nature conservation, the advantage of the promotion and publicity, keeping the future of the hospitality industry, the development of the surrounding communities, and guest satisfaction that is felt by the customer at star hotels in Bali.

\section{Concept}

The concept of environmental management is related to effort of star rated hotels in Bali to become more environmentally friendly. Related to the formulation of the problem, the framework of concept of environmental management at star rated hotel is influenced by three main components namely; environmental issues, environmental management processes, and the perceived benefits of environmental management processes at star rated hotel.

\section{The Environmental Issues}

The environmental issues are the key issues of environment directly or indirectly can be caused by tourism, including hotel management or the others tourism activities affect. Brown (1994), describes the main indicator or the main reason the hotel will be involved in environmental management is due to issues such as; the government regulations, the resource saving, the pressure of Travel Bureau, and customers or tourists. Mycock and Baker (2008) adds an indicator of other issues, climate change, and concerns in others global environmental problems. Dief and Font (2012), also added and other indicator such as; the benefits of cutting operational costs.

\section{Environmental Management Process}

Environmental management system playing very important role in sustainable development (Dalem, 2012). Environmental management at the hotel should include all 
activities that have an impact on the environment and develop practices wider to reduce the environmental impact such as; reducing energy use, control and improve ventilation and cooling equipment, lighting, and other facilities that require energy. Reducing waste such as simultaneously minimizing plastic consumption and packaging, use of a box that can be parsed again, reusable materials, such as glass, paper and garbage collection were selected. According to El Dief and Font (2010), environmental management is catagorized in four areas such as; water and waste water management, energy management, solid waste reduction, and the purchase of products with a green label. Sweeting and Sweeting (2003), draw up a practical guide to good practice environmental management in the accommodation sector, and add the chemicals management at the hotel.

\section{The Benefits of Environmental Management Process}

There are many benefits to be gained from the process of environmental management which is carried out at star rated hotel. However some literature noted that the main benefits gained from the process of environmental management is of financial benefit, employee satisfaction, guest satisfaction, biodiversity and nature conservation, the advantage of the promotion and publicity, keeping the future (sustainability) in hospitality industry, and development of surrounding communities (Feiertag, 1994; Kirk, 1995; Cordeiro and Sarkis, 1997; Dobers, 1997; Davies and Cahill, 2000; Sweeting and Sweeting, 2003; CarmonaMoreno, Céspedes-Lorente and De BurgosJiménez, 2004; Mycock and Baker, 2008). Overall, the framework of the concept of environmental management at the star rated hotel is depicted in Figure 3.2.

\section{Methodology}

This research is a quantitative research, using of the survey design, conducted throughout the star rated hotel in Bali, where the respondent is the manager of the hotel and guests/tourists who has stay, which spread almost throughout the district and cities in Bali, except in the district of Bangli and Jembrana which does not have a star rated hotel. More information will be found in Table 1 .
Tabel 1. The Dissemination Star Rated Hotels in Bali 2014

\begin{tabular}{|c|c|c|c|}
\hline No & District/Cities & Disparda & Sampe \\
\hline 1 & Denpasar & 26 & 22 \\
\hline 2 & Badung & 154 & 80 \\
\hline 3 & Bangli & 0 & 0 \\
\hline 4 & Buleleng & 11 & 5 \\
\hline 5 & Gianyar & 14 & 11 \\
\hline 6 & Jembrana & 0 & 0 \\
\hline 7 & Klungkung & 1 & 1 \\
\hline 8 & Karangasem & 7 & 6 \\
\hline 9 & Tabanan & 4 & 1 \\
\hline \multicolumn{2}{|c|}{ Total } & $\mathbf{2 1 7}$ & $\mathbf{1 2 6}$ \\
\hline
\end{tabular}

\begin{tabular}{|c|c|c|}
\hline $\begin{array}{c}\text { Type of } \\
\text { Star }\end{array}$ & Disparda & Sampel \\
\hline $\begin{array}{c}\text { Star } \\
\text { Rated I }\end{array}$ & 2 & 4 \\
\hline $\begin{array}{c}\text { Star } \\
\text { Rated II } \\
\text { Star } \\
\text { Rated III }\end{array}$ & 14 & 10 \\
\hline $\begin{array}{c}\text { Star } \\
\text { Rated IV }\end{array}$ & 49 & 24 \\
\hline $\begin{array}{c}\text { Star } \\
\text { Rated V } \\
\text { Total }\end{array}$ & 46 & 49 \\
\hline
\end{tabular}

Source: PHRI Bali. 2015

Source: Disparda Bali. 2015

Sampling techniques using purposive sampling approach and the size of the sample using saturated sampling (using the entire population star rated hotels in Bali as respondents). Variables and indicators of research seen in Table 2.

Table 2. Latent variables, Exogenous, endogenous, Manifest and Variables Error

\begin{tabular}{|c|c|c|c|c|}
\hline \begin{tabular}{l|} 
Type \\
of \\
Variab \\
les
\end{tabular} & \multicolumn{4}{|c|}{ Remark } \\
\hline \multirow{8}{*}{$\begin{array}{l}\text { Latent } \\
\text { constr } \\
\text { uct } \\
\text { Exoge } \\
\text { nous }\end{array}$} & \multicolumn{4}{|c|}{ The Issues of Environment } \\
\hline & $\mathrm{x}_{11}$ & \multicolumn{3}{|l|}{ The government regulations } \\
\hline & $\mathrm{x}_{12}$ & \multicolumn{3}{|l|}{ The resource saving } \\
\hline & $\mathrm{x}_{13}$ & \multicolumn{3}{|l|}{ The pressure of Travel Bureau } \\
\hline & $\mathrm{x}_{14}$ & \multicolumn{3}{|l|}{ The pressure of customers or tourists } \\
\hline & $\mathrm{x}_{15}$ & \multicolumn{3}{|l|}{ Climate change } \\
\hline & $\mathrm{x}_{16}$ & \multicolumn{3}{|c|}{ The concerns in others global environmental problems } \\
\hline & $\mathrm{x}_{17}$ & \multicolumn{3}{|c|}{ The benefits of cutting operational costs } \\
\hline \multirow[t]{8}{*}{$\begin{array}{l}\text { Latent } \\
\text { constru } \\
\text { ct } \\
\text { Endoge } \\
\text { nous }\end{array}$} & \multicolumn{2}{|c|}{$\begin{array}{l}\text { The Processes of Environmental Management } \\
\left(\mathbf{Y}_{1}\right)\end{array}$} & \multicolumn{2}{|c|}{\begin{tabular}{|l|} 
The Benefits of \\
Processes \\
Environmental \\
Management $\left(\mathrm{Y}_{2}\right)$ \\
\end{tabular}} \\
\hline & $\mathbf{y}_{11}$ & Energy management & $\mathrm{y}_{21}$ & $\begin{array}{l}\text { Financial } \\
\text { benefits }\end{array}$ \\
\hline & $\mathrm{y}_{12}$ & Water management & $\mathrm{y}_{22}$ & $\begin{array}{l}\text { Employee } \\
\text { satisfaction }\end{array}$ \\
\hline & $\mathrm{y}_{13}$ & Waste water management & $\mathrm{y}_{23}$ & $\begin{array}{l}\text { Guest } \\
\text { satisfaction }\end{array}$ \\
\hline & $\mathrm{y}_{14}$ & Solid waste management & $\mathrm{y}_{24}$ & $\begin{array}{l}\text { Biodiversity } \\
\text { and nature } \\
\text { conservation }\end{array}$ \\
\hline & $\mathrm{y}_{15}$ & Chamical waste management & $\mathrm{y}_{25}$ & $\begin{array}{l}\text { The advantage } \\
\text { of the } \\
\text { promotion and } \\
\text { publicity }\end{array}$ \\
\hline & \multirow[t]{2}{*}{$\mathrm{y}_{16}$} & \multirow{2}{*}{$\begin{array}{l}\text { Purchasing of hotel operational } \\
\text { products }\end{array}$} & $\mathrm{y}_{26}$ & $\begin{array}{l}\text { Sustainability } \\
\text { of hospitality } \\
\text { industry }\end{array}$ \\
\hline & & & $\mathrm{y}_{27}$ & $\begin{array}{l}\text { Development } \\
\text { of } \\
\text { communities } \\
\text { surrounding }\end{array}$ \\
\hline
\end{tabular}


Source: Brown (1994); Feiertag (1994); Kirk (1995); Cordeiro and Sarkis (1997); Dobers (1997); Davies and Cahill (2000); Sweeting and Sweeting (2003); CarmonaMoreno, Céspedes-Lorente and De Burgos-Jiménez (2004); Mycock and Baker (2008); Dief and Font (2012).

Data is collected using a questionnaire and the Likert scale with a range of 1 to 7 . The most positive responses (strongly agree) rated the highest (7) and the most negative responses (strongly disagree) rated lowest (1), where the range of $1.00 \leq \mathrm{x} \leq 1.86$ will be included in the first category is not very important, and so forth until the range of $6.16 \leq \mathrm{x} \leq 7.00$ will be included in the category VII extremely important. Data were analyzed using descriptive statistics and analysis Structural Equation Modelling (SEM).

\section{Results and Discussion}

\section{Descriptive Analysis of Environmental Management at the Hotel Star}

The following are descriptions of research data, which is processed using descriptive statistical analysis, which includes environmental issues, environmental management processes, and the benefits of environmental management at the five-star hotel in Bali.

\section{Environmental Management Issues}

Environmental management issues are analyzed, actual issues of environmental management, which affects five-star hotel, to perform environmental management process. Issues of this issue consists of seven variables, namely; government regulations, saving resources, pressure from travel agents, customer pressure and tourists, climate change (climate change), concerns in other global environmental problems, and the benefits of cutting operational costs. The all of the variables are in the category of very important. Furthermore, the four-star hotel and five issues of environmental management is categorized as very important, while for five-star hotel one, two, and three this important category, with a few exceptions in some indicators.

\section{Empirical Data Support for Theoretical Model}

Results of SEM analysis on environmental management at star rated hotels in Bali are as follow. This distributed data have passed the test assumptions and requirements of SEM analysis, and hypothesis testing models. Exogenous latent variables of the issue of environmental management $(\mathrm{X})$, consist of: $\mathrm{X}_{11}$ government regulations (according to the results of analysis of validity and reliability is invalid), $\mathrm{X}_{12}$ resource savings, $\mathrm{X}_{13}$ pressure from tour operator, $\mathrm{X}_{14}$ customer pressure and tourists, $X_{15}$ climate change, $X_{16}$ concerns in other global environmental problems, and $\mathrm{X}_{17}$ benefits of cutting operating costs. Endogenous latent variable environmental management process (Y1) in the star rated hotel in Bali, consist of: $Y_{11}$ energy of management process, $Y_{12}$ water of management processes, $Y_{13}$ process of wastewater management, $\mathrm{Y}_{14}$ solid waste management process, $\mathrm{Y}_{15}$ chemical management process, and $Y_{16}$ product purchase management process for the operational of the hotel.

Endogenous latent variable of the benefits of environmental management at star rated hotels in Bali, consist of: $Y_{21}$ financial benefits, $Y_{22}$ employee satisfaction, $Y_{23}$ contribution to biodiversity and nature conservation, $\mathrm{Y}_{24}$ benefit from the promotional and publicity, $\mathrm{Y}_{25}$ maintaining the sustainability of the hospitality industry, $\mathrm{Y}_{26}$ contribute to the development of society, $\mathrm{Y}_{27}$ guest satisfaction. Based on the theoretical study of environmental management at hotel, then will be established a theoretical model. Unfortunately this theoretical model after tested for star rated hotel in Bali, using 126 primary data shows the test results do not meet with the criteria of the goodness of fit, as following indicators: Chi-Square $(\chi 2)$ with $\mathrm{p}=$ $0.00(<0.05)$; CFI amounted to $0.714(<0.90)$; TLI amounted to $0.674(<0.90)$; RMSEA with $\mathrm{p}$ equal to 0.145 (>0.05). To get a good model, further modifications of models needed to do, with the confirmatory factor analysis for all variables, and also consider the suggestion by Netmeyer et al. (2003) that any factor should can be represented consist of minimun three of variables, wherein the variables have the highest numbers weighting factor. Furtheremore the final results of the modification model of this structural equation model shown in Figure 1. 


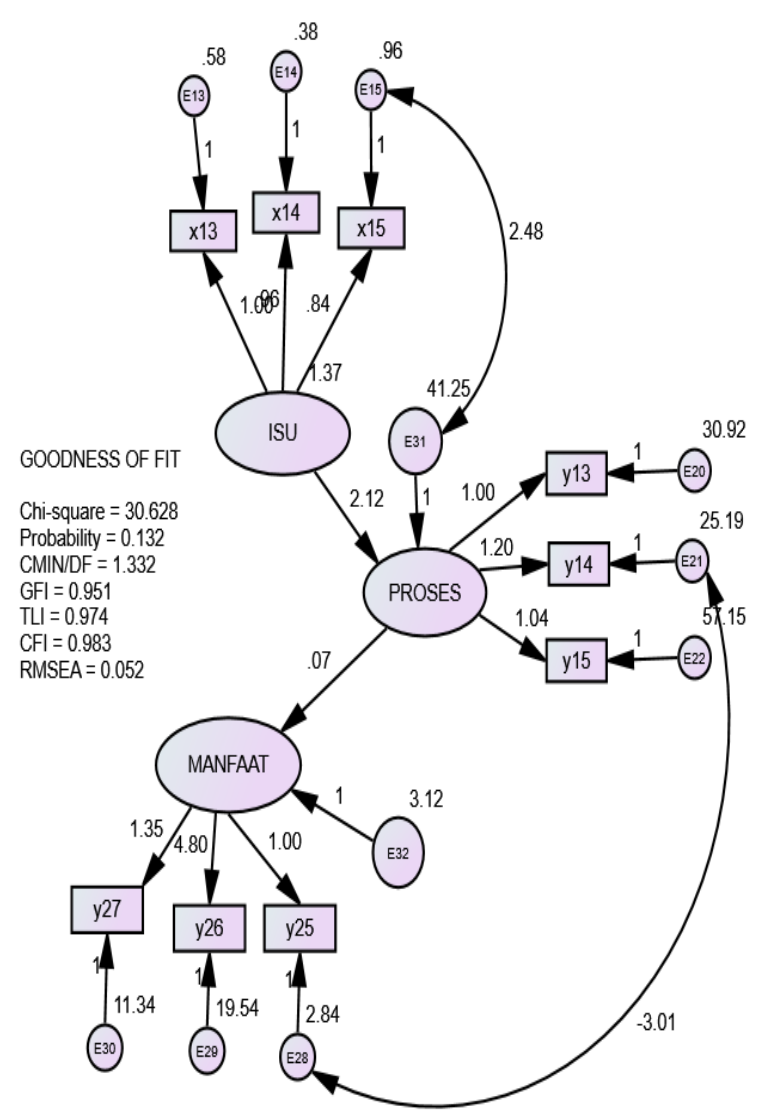

Figure 1. Structural Equation Model Environmental Management at rated hotels in Bali

These modified measurement model has met with the criteria for goodness of fit: ChiSquare $(\chi 2)$ with $\mathrm{p}=0.132(>0.05)$; CFI amounted to 0.983 (> 0.90); TLI amounted to 0,974 (> 0.90); RMSEA with $\mathrm{p}$ equal to 0.052 (approaching 0.05 , actually should be less than 0.05). The fulfillment of the criteria for goodness of fit of this model, fortheremore it can be concluded that the theoretical concept model accordance with the existing empirical data.

The Influence of Environmental Issues (ISSUES) to the Environmental Management Process (PROCESSES) at rated hotels in Bali.

Parameter estimation for testing the effect of the construct $(\mathrm{X})$ environmental issues (ISSUES) which is a major consideration for the hotel managers perform environmental management process to construct $\left(\mathrm{Y}_{1}\right)$ environmental management process (PROCESSES) which carried out the star rated hotel in Bali, indicated by the value of CR and probability, wherein the threshold value of CR is $\geq 1.96$, while the threshold probability is $\leq$ 0.05 . CR value (critical ratio) is 3.378 , and the probability is *** (Zero). Both of these values meet the requirements for admission $\mathrm{H}_{1}$ (alternative hypothesis) and reject $\mathrm{H}_{\mathrm{o}}$. It can be concluded that there is a significant effect, between (X) on environmental issues (ISSUES) which is a major consideration managers star hotels in Bali to make the process of environmental management to $\left(\mathrm{Y}_{1}\right)$ environmental management process (PROCESSES) which is carried out at star rated hotels in Bali.

In other words there is a significant relationship between issues of environment which consists of; the issue of pressure from a travel bureau, customers and tourists pressure issues, and climate change issues to the process of environmental management at star hotels in Bali, which consists of; the process wastewater management, solid waste and chemicals management in star rated hotels in Bali.

The Influences of the Process of Environmental Management (PROCESSES) to the Benefits of Environmental Management (BENEFITS) at Star Rated hotel in Bali

Parameter estimation for testing the effect of the construct $\left(\mathrm{Y}_{1}\right)$ environmental management process (PROCESSES) conducted at star rated hotels in Bali to construct $\left(\mathrm{Y}_{2}\right)$ the perceived benefits of environmental management processes (BENEFITS) at star rated hotel in Bali indicated by the value of $\mathrm{CR}$ and Probability, wherein the threshold value of $\mathrm{CR}$ is $\geq 1.96$, while the threshold probability is $\leq 0.05$. CR value (critical ratio) amounted to 2,434 , and probability 0.015 . Both of these values meet the requirements for admission $\mathrm{H} 1$ (alternative hypothesis) and reject Ho. It can be concluded that there is significant influence between the constructs $\left(\mathrm{Y}_{1}\right)$ environmental management process (PROCESSES) conducted at star rated hotel in Bali to construct $\left(\mathrm{Y}_{2}\right)$ perceived benefits of environmental management processes (BENEFITS) at star rated hotel in Bali. 
In other words, stated that there is significant influence of process waste water management, solid waste management and chemicals against the benefits to the sustainability of the hospitality industry, contribute to the development of society, and guest satisfaction at star retad hotel in Bali. The novelty or research findings of this study suggests a new model of the influence of environmental management issues to the process of environmental management, and to the benefits from the process of environmental managementat the star rated hotel in Bali. The model findings of this study, has been through several stages of testing, and the model is declared fit with existing data, consist of such criteria; RMSEA, GFI, AGFI, TLI and CFI has been declared fit with the requirements modeling, the structural equational models (SEM).

In simple terms, the findings of this study can be stated as follows:

1. There is a significant direct influence between environmental issues to the process of environmental management at star rated hotels in Bali (SWR = 0.36).

2. There is a significant influence between environmental management processes to the benefits of the environmental management process at star rated hotels in Bali (SWR = 0.262 ).

3. The indicators of environmental management issues consist of; the issue of pressure from travel agents, the pressure customers and tourists, and the climate change issues.

4. The indicators process of environmental management at star rated hotels in Bali is consist of; wastewater management processes, the solid waste management processes, and of the chemicals management processes.

5. The indicators benefits of the process of environmental management at the star rated hotel in Bali consist of: the maintaining of hospitality industry, the contribution to the development of society, and the guest satisfaction.

http://ojs.unud.ac.id/index.php/eot

\section{Limitations of the Research}

The model of environmental management at star rated hotels in Bali which is examined in this study showed good results and proved to fit with existing data. Unfortunately there are some of the indicators that make up the constructs (latent variables that exist) to be eliminated when using structural equational models (SEM), so that the formed construct does not fully represent the theoretical model. Elimination of some indicator variables also caused elimination of some information, which should be able to enrich the studies in this research. Also the indicator variable that is not valid (even though the indicators are reliable) also reduces the information, which should be enriched in this study.

\section{Conclusion and Recommendations}

\section{Conclusion}

This research has established the model of environmental management at star hotels in Bali. The model shows that, the issues of environmental influencing the process of environmental management, and the environmental management processes influencing the benefits of the process of environmental management at the star rated hotel in Bali. Forming key indicators of environmental issues are 1) the issues about the pressure of Travel Bureau, 2) issues of customer pressure and tourists, and 3) climate change issues (climate change). While forming key indicators process of environmental management are 1) the process of wastewater management, 2) the process of solid waste management, and 3) the management of chemicals, and the key indicators benefits of environmental management processes are 1) maintain the sustainability of the hospitality industry, 2) contribute to the development of society, and 3) satisfaction of the guests.

\section{Recommendation}

The results showed that the main reason star rated hotels are willing to engage in environmental management is due to pressure from; 1) Travel Bureau, and 2) customers or guests, also for 3) climate change (climate change). The government should be able to consider the role of Travel Agency and guests, 
meaning that the government can educate Travel Bureau and guests on the importance of preserving the environment, and how to maintenance effort, as one of the medium effective for the government to approach the hotel manager to also will jointly carry out the process of environmental management at the five-star hotel in Bali. This is a new approach in the implementation of the rules which indirectly put pressure on hotel managers to perform environmental management. It just requires a deeper study, and can be advanced research fields in the future.

Hotel should be encouraged to actively preserve the assets of the world for generations to come, particularly in the use of natural resources and sustainable environmental conservation efforts, because environmental management activities has potential to develop the ability of the hotel, in terms of integration of stakeholders, continuous innovation, learning processes higher, and consider the sustainability of the hospitality industry, destinations, competitiveness, interaction between stakeholders, and policy instruments to balance economic growth and environmental concerns. Where economic development and environmental issues in relation to the assessment of stakeholders that need to be investigate deeper in advanced research in the future. The hotel should be push to do the process of environmental management, because the most significant benefits of environmental management for the hotel is a better relationship with the community (improvement of public image), it has become a trend, and tourists preferred. Results of this study found the willingness of tourists to o pay for and educated on how to minimize their impact on the environment, and also can affect the hotel suppliers to provide products that are environmentally friendly.

Model of environmental management at star hotels in Bali fit with existing data, but some indicators that make up the construct eliminated, so the construct that is formed is not fully represent the theoretical model. The elimination of indicators also eliminate some informations which should be able to enrich the study. Therefore, it is advisable to carry out the selection of indicators that truly represents its latent variable by doing unidemensional test first before conducting a survey. It also needs to add a mixed methods approach because the various problems that exist around environmental management at the star rated hotel cannot be answered by a quantitative approach only, and this weakness can be covered by a qualitative approach.

\section{References}

Alexander, S. and Kennedy, C. (2002) 'Green hotels: Opportunities and resources for success', Zero Waste Alliance, 5(7), pp. $1-9$.

Asean Green Hotel (2012) Buku Panduan Penilaian Green Hotel Award. Jakarta Pusat: Kementerian Kebudayaan dan Pariwisata.

Banerjee, S. B. (2001) 'Corporate environmental strategies and actions', Management Decision, 39(1), pp. 3646.

Bohdanowicz, P. (2006) 'Environmental awareness and initiatives in the Swedish and Polish hotel industries-survey results', International Journal of Hospitality Management. Elsevier, 25(4), pp. 662-682.

Brown, M. (1994) 'Environmental auditing and the hotel industry: an accountant's perspective', Tourism: The state of the art. John Wiley and Sons Chichester, pp. 675-681.

Carmona-Moreno, E., Céspedes-Lorente, J. and De Burgos-Jiménez, J. (2004) 'Environmental strategies in Spanish hotels: contextual factors and performance', The Service Industries Journal. Taylor \& Francis, 24(3), pp. 101-130.

Cordeiro, J. J. and Sarkis, J. (1997) 'Environmental proactivism and firm performance: evidence from security analyst earnings forecasts', Business Strategy and the Environment. Wiley Online Library, 6(2), pp. 104-114. 
Cramer, J. (1998) 'Environmental management: from "fit"to "stretch", Business strategy and the Environment. Wiley Online Library, 7(3), pp. 162-172.

Dalem, A. A. G. R. (2012) 'Sistem manajemen lingkungan, Tri Hita Karana dan implementasinya pada hotel'. Udayana University.

Davies, T. and Cahill, S. (2000) Environmental implications of the tourism industry. Resources for the Future Washington, DC.

Dief, M. El and Font, X. (2012) 'Determinants of environmental management in the Red Sea Hotels: personal and organizational values and contextual variables', Journal of Hospitality \& Tourism Research. SAGE Publications Sage CA: Los Angeles, CA, 36(1), pp. 115-137.

Dobers, P. (1997) 'Strategies for environmental control: a comparison between regulation and centralized control in Germany and reforms leading to decentralized control in Sweden', Business Strategy and the Environment. Wiley Online Library, 6(1), pp. 34-45.

Feiertag, H. (1994) 'Boost sales with environment-driven strategy.', Hotel \& Motel Management. Advanstar Communications Inc., 209(2), p. 8.

Gustin, M. E. and Weaver, P. A. (1996) 'Are hotels prepared for the environmental consumer?', Hospitality Research Journal. Sage Publications Sage CA: Thousand Oaks, CA, 20(2), pp. 1-14.

H. Raedeke Charles H. Nilon, Andrew, J. S. R. (2001) 'Ecosystem management and landowner concern about regulations: a case study in the Missouri Ozarks', Society \&Natural Resources. Taylor \& Francis, 14(9), pp. 741-759.
Hajjah, F. and Decelle, F. X. (2011) 'Manajemen Lingkungan Hotel di Bali: Penerapan Konsep Ekologi Dalam Kegiatan Hotel', Jurnal Ilmiah Pariwisata, 2(1).

Henriques, I. and Sadorsky, P. (1996) 'The determinants of an environmentally responsive firm: an empirical approach', Journal of environmental economics and management. Elsevier, 30(3), pp. 381-395.

Houdré, H. (2008) 'Sustainable Development in the hotel industry'.

Iwanowski, K. and Rushmore, C. (1994) 'Introducing the eco-friendly hotel', The Cornell Hotel and Restaurant Administration Quarterly. Elsevier, 35(1), pp. 34-38.

Khanna, M. and Damon, L. A. (1999) 'EPA's voluntary $33 / 50$ program: Impact on toxic releases and economic performance of firms', Journal of environmental economics and management. Elsevier, 37(1), pp. 1-25.

Kirk, D. (1995) 'Environmental management in hotels', International journal of contemporary hospitality management. MCB UP Ltd, 7(6), pp. 3-8.

Kirk, D. (1998) 'Attitudes to environmental management held by a group of hotel managers in Edinburgh', International Journal of Hospitality Management. Elsevier, 17(1), pp. 33-47.

Lensiana (2010) Partisipasi Hotel dalam Pengelolaan Lingkungan di Kecamatan Ubud, Kabupaten Gianyar. Studi Kasus Terhadap Sistem Pengelolaan Limbah Hotel. Universitas Udayana.

Manaktola, K. and Jauhari, V. (2007) 'Exploring consumer attitude and behaviour towards green practices in the lodging industry in India', International Journal of Contemporary Hospitality Management. Emerald Group Publishing Limited, 19(5), pp. 364-377. 
Meegeren, P. Van (2001) 'Blue bags or refuse tourism: Social acceptance of closed policymaking', Society \& Natural Resources. Taylor \& Francis, 14(1), pp. 77-86.

Mensah, I. (2006) 'Environmental management practices among hotels in the greater Accra region', International Journal of Hospitality Management. Elsevier, 25(3), pp. 414-431.

Mycock, S. and Baker, C. (2008) 'Environmental Management for Hotels: The Industry Guide to Sustainable Operation by International Tourism Partnership'.

Russo, M. V and Fouts, P. A. (1997) 'A resource-based perspective on corporate environmental performance and profitability', Academy of management Journal. Academy of Management, 40(3), pp. 534-559.

Solihin, A. H. (2014) 'Penerapan Prinsip Tri Hita Karanadalam Pengelolaan Vila di Kelurahan Seminyak Kuta'.

Sweeting, J. E. N. and Sweeting, A. R. (2003) 'A Practical Guide to Good Practice, Managing Environmental and Social Issues in the Accommodation Sector', The centre for environmental leadership in business and the tour operators' initiative for sustainable tourism development.

Tzschentke, N. A., Kirk, D. and Lynch, P. A. (2008) 'Going green: Decisional factors in small hospitality operations', International Journal of Hospitality Management. Elsevier, 27(1), pp. 126133.

UNWTO (2009) From Davos to Copenhagen and Beyond: Advancing Tourisms Response to $C$ te Change. Available at: http://sdt.unwto.org/sites /all/files/docpdf/fromdavostocopenhage nbeyondunwtopaperelectronicversion.p df. (Accessed: 3 May 2012).
Utami, N. M. M. (2004) 'Dampak industri pariwisata terhadap kualitas air tanah di Kuta, Bali'. Pasca Sarjana-UI.

Winter, S. C. and May, P. J. (2001) 'Motivation for compliance with environmental regulations', Journal of Policy Analysis and Management. Wiley Online Library, 20(4), pp. 675-698.

Yol Lee, S. and Rhee, S.-K. (2007) 'The change in corporate environmental strategies: a longitudinal empirical study', Management Decision. Emerald Group Publishing Limited, 45(2), pp. 196-216.

Zhang, J. J., Joglekar Ph D, N. and Verma Ph D, R. (2010) 'Developing measures for environmental sustainability in hotels: An exploratory study'. 